\title{
Superior Optic Vein Thrombosis Related to Orbital Cellulitis Secondary to Aquatic Injury
}

\author{
Zeynep Günes Ozunal ${ }^{1}$, Sibel Karsidag ${ }^{2}$, Sevki Sahin ${ }^{2}$ \\ 1. Medical Pharmacology, Maltepe University, İstanbul, TUR 2. Neurology, Maltepe University, İstanbul, TUR
}

Corresponding author: Zeynep Günes Ozunal, zeynep.ozunal@maltepe.edu.tr

\begin{abstract}
A 52-year-old woman presented with orbital cellulitis and sixth cranial nerve palsy as a result of striking the tail of a stingray while swimming. Her ophthalmologic and neurologic examination showed injury of the conjunctiva, corneal abrasion without mention of foreign body, contusion of the eyelid, and isolated lateral gaze palsy and ptosis in the right eye. Orbital magnetic resonance (MR) imaging and MR venography showed orbital cellulitis, superior and lateral rectus edema, and thrombosis of the superior ophthalmic vein on the right eye. She was treated appropriately, and her physical examination showed significant improvement within three months.
\end{abstract}

Categories: Emergency Medicine, Neurology, Infectious Disease

Keywords: pharmacotherapy, thrombosis, cellulitis

\section{Introduction}

Stingrays are cartilaginous fish that live in salt and fresh water and comprise one of the larger groups of venomous marine animals [1]. The incidence of stingray injury in freshwater is 1.7/100 [2]. Some stingray injuries can be accompanied by infection, toxic effect, and infection by marine bacteria (in $9 \%$ of cases) [2-4]. Venom from sea creatures can exacerbate aquatic injuries. Most ocular injuries are conjunctival or corneal abrasions or corneal foreign bodies, and while orbital cellulitis is rare, it is one of the more dangerous complications. We present a case of severe orbital cellulitis resulting from a stingray strike.

Received 02/05/2020 Review began 02/15/2020 Review ended 02/20/2020 Published 02/23/2020

๑) Copyright 2020 Ozunal et al. This is an open access article distributed under the terms of the Creative Commons Attribution License CC-BY 4.0., which permits unrestricted use, distribution, and reproduction in any medium, provided the original author and source are credited.

\section{Case Presentation}

A 52-year-old woman had a history of travel to Phuket Island. She reported seeing a stingray while staring at the bottom of the sea with her naked eye; the stingray suddenly moved, hitting her right eye with its tail. An ocular dressing was initially placed by a nurse at the beach. She was admitted to the local emergency department when eyelid swelling, ocular pain with movement, diplopia, nausea, and diarrhea developed three hours later. Her initial laboratory test results were as follows: hemoglobin, $13 \mathrm{mg} / \mathrm{dl}$; white blood cell count, $4.3 \times 10^{3} / \mathrm{mm}^{3}$, platelet count, $247 \times 10^{3} / \mathrm{mm}^{3}$; and erythrocyte sedimentation rate, $59 \mathrm{~mm} /$ hour. Ophthalmic antibiotic drops and oral amoxicillin-clavulanate (2000 mg/day) were administered. She subsequently urgently returned to her home country. She was found to have a corneal injury that was repaired by an ophthalmologist. The patient was then referred to our neurology department for consultation. Ophthalmologic and neurologic examination showed injury to the conjunctiva, corneal abrasion without mention of foreign body, eyelid contusion, and isolated right eye lateral gaze palsy and ptosis. Visual acuity was 20/20, eye pressures were 19 and $15 \mathrm{mmHg}$ in the right and left eye, respectively. Soft tissue swelling with hematoma of the right eyelid and periorbital area including the post-septal area at the lateral extraconal fat of the right orbit were shown on orbital computed tomography. Orbital magnetic resonance (MR) imaging and MR venography showed orbital cellulitis, superior and lateral rectus edema, and thrombosis of the right superior ophthalmic vein (Figure 1A, 1B). 


\section{Cureus}
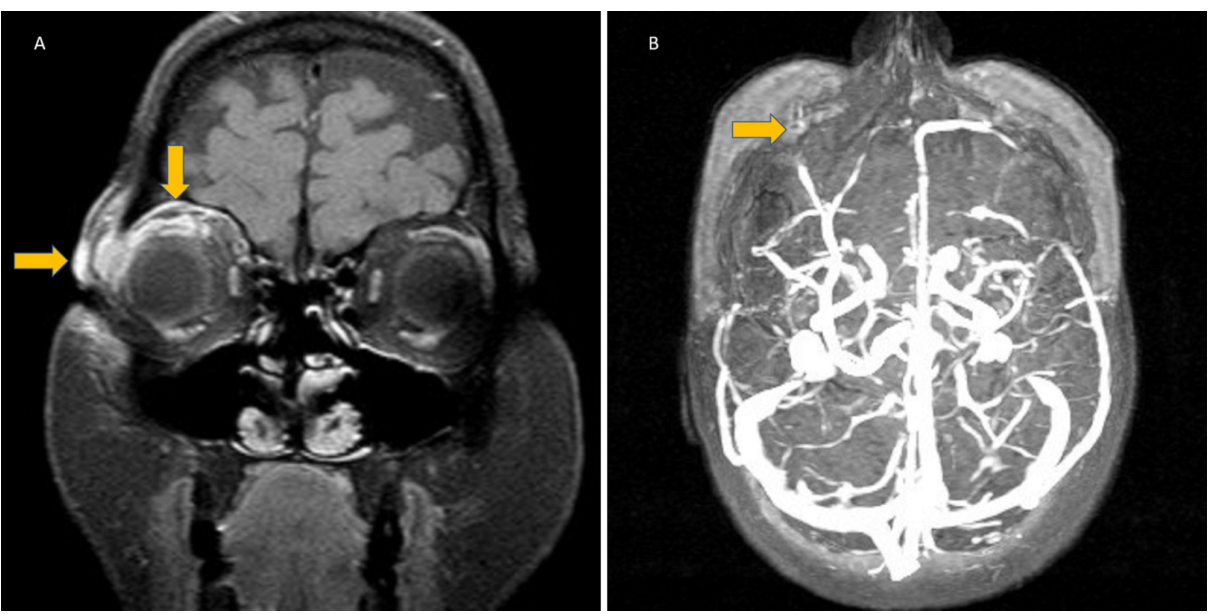

FIGURE 1: (A) The T1 SPIR contrast enhancement on a coronal MRI slice shows subcutaneous edema, periorbital cellulitis at the right eye. (B) Filling defect due to thrombosis of superior ophthalmic vein on the right eye.

SPIR: Spectral presaturation with inversion recovery; MRI: Magnetic resonance imaging.

The diagnosis was established as orbital cellulitis and local venous thrombosis. Enoxaparin 6000 IU and prednisolone $60 \mathrm{mg}$ per day were started for six weeks. Her examination showed significant improvement after three months.

\section{Discussion}

Stingray strike injury sites are usually the distal lower extremity. Thoraco-abdominal stingray spine injuries are rare but can cause mortality due to cardiac complications [1]. Stingray injuries can be complicated by poor wound healing, tissue necrosis, and bacteremia. Medical treatment can often involve surgical wound debridement. It has been reported that the incidence of associated infection can be as high as $9 \%$ [2]. Orbital cellulitis represents a major infection of orbital tissues. Various patterns of contiguous spread can cause orbital cellulitis such as direct invasion from paranasal infection, direct inoculation from trauma, or hematogenous spread from bacteremia [5].

Generally, stingray strike injury occurs due to deep penetration and retraction of the stingray's barbed tail spine into the soft tissue, causing physical trauma to the tissues in addition to the physiological response to the spine's venom, which contributes to widespread tissue damage. Stingray injury can occasionally be accompanied by toxic effects and inoculation by marine bacteria. Such cases are painful and more likely to be associated with septic complications. Empiric antibiotic therapy should be started [6]. Superior ophthalmic vein thrombosis is an uncommon orbital pathology that is frequently associated with cavernous sinus thrombosis. Vascular injury, stasis, and hypercoagulability may cause cerebral vein thrombosis $[7,8]$. Our patient's case included these risk factors, and the thrombosis affected the superior orbital vein.

\section{Conclusions}

We report aquatic ocular injury-related orbital cellulitis caused by a stingray attack in a 52-year-old woman. The patient's orbital cellulitis is believed to have been caused by both the stingray injury and associated marine bacteria inoculation. Physicians should be aware of the consequences of aquatic injuries related to poisonous fish and stingrays.

\section{Additional Information \\ Disclosures}

Human subjects: Consent was obtained by all participants in this study. Conflicts of interest: In compliance with the ICMJE uniform disclosure form, all authors declare the following: Payment/services info: All authors have declared that no financial support was received from any organization for the submitted work. Financial relationships: All authors have declared that they have no financial relationships at present or within the previous three years with any organizations that might have an interest in the submitted work. Other relationships: All authors have declared that there are no other relationships or activities that could appear to have influenced the submitted work. 


\section{Cureus}

\section{References}

1. Srinivasan S, Bosco JI, Lohan R: Marine stingray injuries to the extremities: series of three cases with emphasis on imaging. J Postgrad Med. 2013, 59:309-311. 10.4103/0022-3859.123163

2. Sachett JAG, Sampaio VS, Silva IM, et al.: Delayed healthcare and secondary infections following freshwater stingray injuries: risk factors for a poorly understood health issue in the Amazon. Rev Soc Bras Med Trop. 2018, 51:651-659. 10.1590/0037-8682-0356-2017

3. Do R, Lu LQ, Strauss MB: Toxic inoculation associated with a presumptive stingray injury . Undersea Hyperb Med. 2019, 46:719-722.

4. Han H, Baumann K, Casewell NR, et al.: The cardiovascular and neurotoxic effects of the venoms of six bony and cartilaginous fish species. Toxins (Basel). 2017, 9:67. 10.3390/toxins9020067

5. Stead TG, Retana A, Houck J, Sleigh BC, Ganti L: Preseptal and postseptal orbital cellulitis of odontogenic origin. Cureus. 2019, 11:5087. 10.7759/cureus.5087

6. Otten EJ: Venomous animal injuries. In Rosen's Emergency Medicine: Concepts and Clinical Practice. Walls RM, Hockberger RS, Gausche-Hill M (ed): Elsevier, Philadelphia; 2018. 9:698-714.

7. Lim LH, Scawn RL, Whipple KM, Oh SR, Lucarelli MJ, Korn BS, Kikkawa DO: Spontaneous superior ophthalmic vein thrombosis: a rare entity with potentially devastating consequences. Eye (Lond). 2014, 28:348-351. 10.1038/eye.2013.273

8. Cumurcu T, Demirel S, Keser S, Bulut T, Cavdar M, Doğan M, Saraç K: Superior ophthalmic vein thrombosis developed after orbital cellulitis. Semin Ophthalmol. 2013, 28:58-60. 10.3109/08820538.2012.736007 